\title{
Analysis and Control for Heavy Equipment Spare Parts Inventory in the Nickel Mining Industry
}

\author{
Sri Rahayu Pardede and Iwan Vanany \\ Departement of Industrial and System Engineering, Institut Teknologi Sepuluh Nopember, Surabaya \\ e-mail:Sri.Pardede@vale.com
}

\begin{abstract}
In the mining industry, analyzing, and controlling the spare parts inventory is important activities and need special attention from the company. The high production cost of the mining industry, including spare parts and shortages costs affects the financial and operational aspects of the company. Spare parts inventory management policy is critical to increase the service level and minimize spare parts cost. In this mining case study, the out of stock incidents in the heavy equipment spare parts were often occurring and significantly affecting the performance of maintenance and operations. The purpose of this study is to determine minimum stock (safety stock) and maximum stock to reduce overstocks and reduce the number of stocks out in spare parts inventory and as well as inventory cost. The method used to solve the problem is economic order quantity (EOQ) and continuous review control $(S, s)$ to determine the minimum and maximum stocks. Determining the combination of $S$ and $s$ has a major impact on the success of inventory control. Substitution parts are subdivided into alphabetical values to determine their significance. As a result of calculating inventory value using EOQ and $S$, $s$ will get the highest inventory value to reduce inventory costs.
\end{abstract}

Keywords-Continuous Review Control, Economic Order Quantity, Heavy Equipment, Inventory, Mining Industry.

\section{INTRODUCTION}

$\mathrm{I}_{\mathrm{a}}^{\mathrm{N}}$ NVENTORY management is one of the most important activities in a company. That is because there is money embedded from inventory stored by the company [1]. The reason companies need to provide inventory is due to three things: time, uncertainty and economic of scale [2]. The company's goal in terms of effectiveness and efficiency will be achieved if this inventory is managed properly. In inventory management, if the management is not good it will cause conditions that cause increased costs in a company. With a large amount of equipment, the company made various efforts to maintain the equipment to operate properly, including doing routine and non-routine maintenance. This maintenance activity is inseparable from the planning and control of spare parts inventory. This is very important for the company so that the company can operate well and get maximum profit.

Stock out often occurs where spare parts often run out in the warehouse before the next order period. For slow moving spare parts, the category usually raises its own dilemma because its use is sparse but needed, and when the company provides too many spare parts in the warehouse it will affect the company's inventory costs. The Figure 1 shows stock out in heavy equipment spare part in 2019 and Figure 2 describes overstock in 2019.

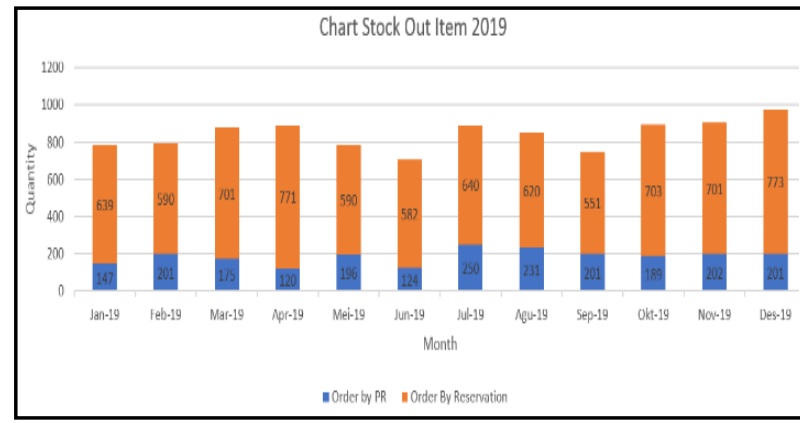

Figure 1. Stock out item in 2019.

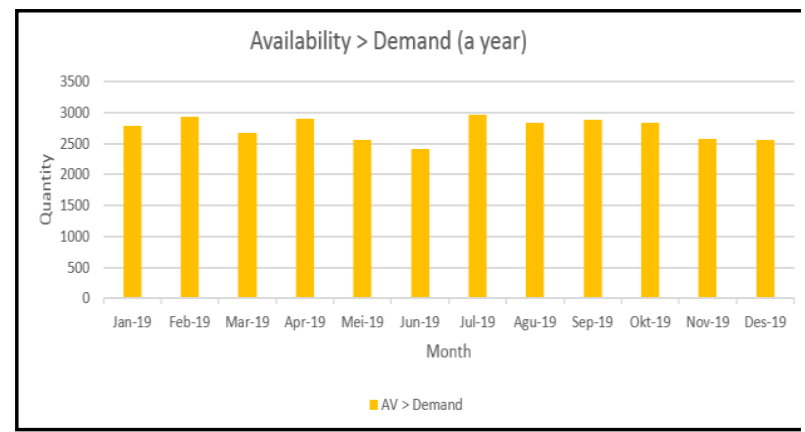

Figure 2. Overstock in heavy equipment spare parts in 2019.

Several previous study in spare part inventory and other research topics were conducted in mining and related industries particularly in Indonesian [3-7]. A new hybrid spares demand forecasting method in mining companies was developed to solve lumpy demand problem by Rosienkiewicz et al [3]. Evaluation of shortage spare parts risks in estimation of the required number of spare parts in Iron ore mining industry was investigated by Ghodrati, et al [4]. FMEA methods was used to analysis risks in equipment including spare parts in oil and gas industry [5] Risk assessment to mitigate risk in compressed natural gas industry [6] and environment performance in gas industry [7] were also investigated. The objective of this study is to determine the minimum and maximum stocks using the EOQ methods and continuous review periodic for heavy equipment in nickel mining industry.

\section{LITERATURE REVIEW}

\section{A. Spare Part Inventory Management}

One of the main supporting activities in the maintenance of heavy equipment for mining companies is spare part management and maintenance management. Spare parts are needed to maintain the availability of the heavy equipment to 
The $6^{\text {th }}$ International Seminar on Science and Technology (ISST) 2020

July $25^{\text {th }} 2020$, Institut Teknologi Sepuluh Nopember, Surabaya, Indonesia

Table 1.

Spare parts stock out data in 3 years

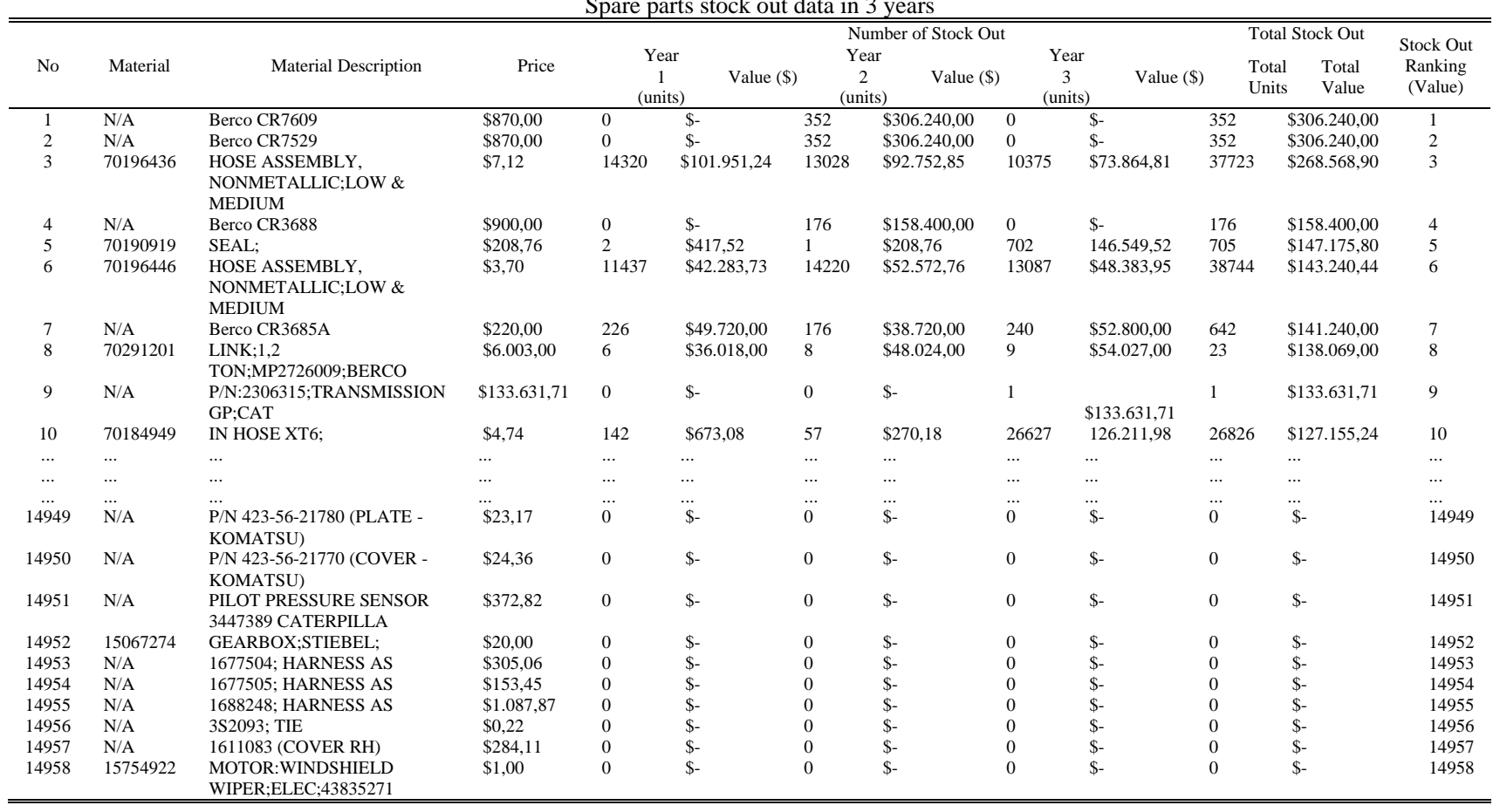

keep it in good condition and can be operated properly [8]. When heavy equipment requires the repair or replacement of certain parts that are damaged or replaced due to damage to corrective maintenance, preventive maintenance, and predictive maintenance, then spare parts become important things needed at that time.

Spare part management is a process that includes the planning, procurement, and supervision of the level of spare parts inventory carried out by the company to achieve the optimal amount of spare parts inventory. Spare parts inventory management regulates the exact level of spare parts inventory so that the amount is not too large and not too small. Inventory management is a process that includes the process of planning, procurement and supervision of the level of inventory needed by the company to reach the optimal amount [9]. Mistakes in determining the amount of spare parts inventory investment will reduce the profits of the company because the high and low levels of inventory turnover will directly affect the size of the funds invested in spare parts inventory. The higher the level of spare parts inventory turnover, the shorter the period of funds embedded in the spare parts inventory. Improper management of spare part inventory will adversely affect the company. The impact of mismanagement of spare parts inventory including [1], filled storage capacity of goods in the warehouse, so that goods cannot be accommodated in the area Warehouse, costs borne by large companies due to lack of efficiency in managing inventory, and stock out occurs so the company suffers a loss due to lost sales / backorder

Proper spare part management will have an impact on the smooth production. The smooth production process will be realized if the process of managing spare parts inventory is carried out in a timely manner, in the right amount, in the right quality, in the right place and in the right price. Spare part inventory management is the process of managing or managing spare parts inventory of goods owned by a company to be sold to consumers. Management or arrangement of the spare part inventory starts from how to get spare part inventory and storage of spare part inventory. Spare parts inventory management has several roles for a company, one of which is to find a balanced stage between the company's costs and the costs required for the costs of procuring spare parts, and storage. It aims to achieve the maximum supply of spare parts with the lowest possible cost. The main functions of inventory are (1) to keep the production process can continue without depending on the demand and supply of raw materials from suppliers [10]. To balance production with distribution [11]. To provide a stock of goods to meet the anticipated demand that will arise from consumers. [12]. There are two policy models in controlling inventory. The two policies are based on the demand rate. These policies are deterministic models and probabilistic models.

If the simulation model does not have a probabilistic (random) component, then the model is called deterministic. The deterministic model is an inventory system whose parameters and all variables are known with certainty. In a deterministic model, the output results are "determined" when several inputs and relationships in the model are established. All parameters in this model are considered unchanged or fixed. The deterministic model in inventory is related to inventory, where actual demand is assumed to be known. The basis for determining the number of orders in the deterministic model is the EOQ (economic order quantity) model which is a demand control technique to reach the optimal point at a low cost. EOQ calculations can be done using the following formula (1).

$E O Q=\sqrt{\frac{2 k \lambda}{h}}$ 
The $6^{\text {th }}$ International Seminar on Science and Technology (ISST) 2020

July $25^{\text {th }} 2020$, Institut Teknologi Sepuluh Nopember, Surabaya, Indonesia

Table 2 .

Ordering cost, holding cost and shortage cost

\begin{tabular}{|c|c|c|c|c|c|}
\hline $\begin{array}{l}\text { Material } \\
\text { Code }\end{array}$ & Material Description & Product Price & $\begin{array}{c}\text { Order } \\
\text { Cost/Unit }\end{array}$ & $\begin{array}{c}\text { Holding } \\
\text { Cost/Unit }\end{array}$ & $\begin{array}{c}\text { Shortage } \\
\text { Cost/Unit }\end{array}$ \\
\hline N/A & P/N:2306315;TRANSMISSION GP;CAT & $\$ 133.631,71$ & $\$ 6.681,59$ & $\$ 12.026,85$ & $\$ 13.363,17$ \\
\hline 70291201 & LINK;1,2 TON;MP2726009;BERCO & $\$ 6.003,00$ & $\$ 300,15$ & $\$ 540,27$ & $\$ 600,30$ \\
\hline N/A & Berco CR3688 & $\$ 900,00$ & $\$ 45,00$ & $\$ 81,00$ & $\$ 90,00$ \\
\hline N/A & Berco CR7609 & $\$ 870,00$ & $\$ 43,50$ & $\$ 78,30$ & $\$ 87,00$ \\
\hline N/A & Berco CR7529 & $\$ 870,00$ & $\$ 43,50$ & $\$ 78,30$ & $\$ 87,00$ \\
\hline N/A & Berco CR3685A & $\$ 220,00$ & $\$ 11,00$ & $\$ 19,80$ & $\$ 22,00$ \\
\hline 70190919 & SEAL; & $\$ 208,76$ & $\$ 10,44$ & $\$ 18,79$ & $\$ 20,88$ \\
\hline 70196436 & HOSE ASSEMBLY, NONMETALLIC;LOW \& MEDIUM & $\$ 7,12$ & $\$ 0,36$ & $\$ 0,64$ & $\$ 0,71$ \\
\hline 70184949 & IN HOSE XT6; & $\$ 4,74$ & $\$ 0,24$ & $\$ 0,43$ & $\$ 0,47$ \\
\hline 70196446 & HOSE ASSEMBLY, NONMETALLIC;LOW \& MEDIUM & $\$ 3,70$ & $\$ 0,18$ & $\$ 0,33$ & $\$ 0,37$ \\
\hline
\end{tabular}

Tabel 3.

Spare parts classification

\begin{tabular}{|c|c|c|c|c|}
\hline No & Material & Material Description & Price & Class \\
\hline 1 & & P/N:2306315;TRANSMISSION GP;CAT & $\$ 133.631,71$ & A \\
\hline 2 & 70161797 & TRANSMISSION ASSEMBLY;;FOR 966E WHEEL & $\$ 56.000,00$ & A \\
\hline 3 & 9L9089:AA & ENGINE & $\$ 42.519,47$ & A \\
\hline 4 & 9M2828:AA & ENGINE & $\$ 30.564,23$ & A \\
\hline 5 & & 312-2232 (WHEEL AS) & $\$ 17.122,52$ & $\mathrm{~A}$ \\
\hline$\ldots$ & $\ldots$ & $\ldots$ & $\ldots$ & $\ldots$ \\
\hline 1324 & 70195122 & HOSE ASSEMBLY;USED ON WHEEL LOADER & $\$ 379,20$ & $\mathrm{~B}$ \\
\hline 1325 & 70196280 & HOSE;1IN; SAE100R13; & $\$ 379,20$ & $\mathrm{~B}$ \\
\hline 1326 & 70196292 & HOSE;3/4IN; SAE100R13; & $\$ 379,20$ & $\mathrm{~B}$ \\
\hline 1327 & 70196296 & HOSE;3/8IN; SAE100R2 AT; & $\$ 379,20$ & $\mathrm{~B}$ \\
\hline 1328 & 70196298 & HOSE;1/2IN; SAE100R2 AT; & $\$ 379,20$ & $\mathrm{~B}$ \\
\hline$\ldots$ & $\cdots$ & .. & $\ldots$ & $\ldots$ \\
\hline 14954 & & 13575231 (OIL PUMP) & $\$ 0,01$ & $\mathrm{C}$ \\
\hline 14955 & & 55028279 (WIRE ROPE) & $\$ 0,01$ & $\mathrm{C}$ \\
\hline 14956 & & 55028297 (WIRE ROPE) & $\$ 0,01$ & $\mathrm{C}$ \\
\hline 14957 & & 5P-5824 (holder) & $\$ 0,01$ & $\mathrm{C}$ \\
\hline 14958 & & H45732 (TUBE) & $\$ 0,01$ & $\mathrm{C}$ \\
\hline
\end{tabular}

Whereas:

$\mathrm{k}=$ order cost

$\lambda=$ demand

$\mathrm{h}=$ holding cost

The deterministic model can be static, namely the inventory model in which the quantity of orders is only done once, the inventory is always fixed / limited within a certain period. Or is dynamic, where demand is known with certainty (continuous) or repeatedly but varies from one period to the next period.

If an inventory model has one or more components whose phenomenon is not known with certainty, but the expected value, variance and distribution patterns are likely to be predictable then the inventory model is said to be probabilistic.

\section{B. Inventory Control System}

Inventory control systems are known as replenishment policies. There are 2 types of replenishment policies, namely periodic review control and continuous review control [13].

\section{1) Periodic Review Control}

Periodic review control is a method of inventory control in which the amount or condition of inventory is monitored at certain intervals. There are two types of review systems in the periodic review control, namely $(\mathrm{R}, \mathrm{S})$ and $(\mathrm{R}, \mathrm{s}, \mathrm{S})$ [14]. Control system $(\mathrm{R}, \mathrm{S})$ is a control system in which inventory control and execution of orders will be made every $\mathrm{R}$ with the number of orders made must reach the maximum point or point $\mathrm{S}$. The control system $(\mathrm{R}, \mathrm{s}, \mathrm{S})$ is a combined control system between $(\mathrm{s}, \mathrm{S})$ with $(\mathrm{R}, \mathrm{S})$. R functions as the control period carried out for inventory control, $\mathrm{S}$ as the maximum point of inventory and $\mathrm{s}$ is the minimum point of total inventory. $\mathrm{s}$ often used as a reorder point or reorder raw materials to suppliers.

\section{2) Continuous Review Control}

Continuous Review Control is a method of inventory control in which the amount or condition of inventory is monitored continuously. In this method there are two types of control systems, namely (s, Q) and (s, S) [9]. The control system (s, Q) is a control system where the order is placed when the amount of inventory is at point $\mathrm{s}$ or at the reorder point. The size of orders placed on this system is fixed, that is, the number of $\mathrm{Q}$. The control system $(\mathrm{s}, \mathrm{S})$ is a control system that orders when the inventory is at point $\mathrm{s}$ or reorder point. The size of the order is determined by the number reaching the maximum point that is $\mathrm{S}$, so the number of orders in this system can change. The following inventory calculation using the control system $(\mathrm{s}, \mathrm{S})$.

$K=\frac{B D-h Q}{B D}$

Safety factor value $=$ NORMSINV (service level)

$s=($ demand $\times$ average lead time $)+$ $(\sigma L \times$ safety factor value $)$

$S=Q+S$

Whereas:

$\mathrm{Q}=$ Order Quantity

$\mathrm{K}=$ Safety Factor

$\mathrm{D}=$ Total Requests 
Table 4.

Demand classification

\begin{tabular}{|c|c|c|c|c|}
\hline $\begin{array}{l}\text { Material } \\
\text { Code }\end{array}$ & Material Description & $\begin{array}{l}\text { Coefficient of } \\
\text { Variation (CV) }\end{array}$ & $\begin{array}{l}\text { Average Demand } \\
\text { Interval (ADI) }\end{array}$ & Classification \\
\hline N/A & P/N:2306315;TRANSMISSION GP;CAT & 2.24 & 6.00 & LUMPY \\
\hline 70184949 & IN HOSE XT6; & 1.59 & 1.00 & ERRATIC \\
\hline 70196436 & HOSE ASSEMBLY, NONMETALLIC;LOW \& MEDIUM & 1.35 & 1.00 & ERRATIC \\
\hline 70196446 & HOSE ASSEMBLY, NONMETALLIC;LOW \& MEDIUM & 0.78 & 1.00 & ERRATIC \\
\hline 70291201 & LINK;1,2 TON;MP2726009;BERCO & 0.75 & 1.29 & ERRATIC \\
\hline 70190919 & SEAL; & 0.58 & 1.00 & ERRATIC \\
\hline N/A & Berco CR3688 & 0.24 & 1.00 & SLOW MOVING \\
\hline N/A & Berco CR3685A & 0.18 & 1.00 & SLOW MOVING \\
\hline N/A & Berco CR7609 & 0.13 & 1.00 & SLOW MOVING \\
\hline N/A & Berco CR7529 & 0.09 & 1.00 & SLOW MOVING \\
\hline
\end{tabular}

Table 5.

Determining EOQ results

\begin{tabular}{|c|c|c|c|c|c|}
\hline $\begin{array}{c}\text { Material } \\
\text { Code }\end{array}$ & Material Description & Order Cost & $\begin{array}{c}\text { Holding } \\
\text { Cost }\end{array}$ & Demand & EOQ \\
\hline N/A & P/N:2306315;TRANSMISSION GP;CAT & $\$ 6.681,59$ & $\$ 12.026,85$ & 0.17 & 0.43 \\
\hline 70291201 & LINK;1,2 TON;MP2726009;BERCO & $\$ 300,15$ & $\$ 540,27$ & 4 & 2.11 \\
\hline N/A & Berco CR3688 & $\$ 45,00$ & $\$ 81,00$ & 129 & 11.97 \\
\hline N/A & Berco CR7529 & $\$ 43,50$ & $\$ 78,30$ & 384 & 20.66 \\
\hline N/A & Berco CR7609 & $\$ 43,50$ & $\$ 78,30$ & 394 & 20.92 \\
\hline N/A & Berco CR3685A & $\$ 11,00$ & $\$ 19,80$ & 124 & 11.74 \\
\hline 70190919 & SEAL; & $\$ 10,44$ & $\$ 18,79$ & 47 & 7.23 \\
\hline 70196436 & HOSE ASSEMBLY, NONMETALLIC;LOW \& MEDIUM & $\$ 0,36$ & $\$ 0,64$ & 981 & 33.02 \\
\hline 70184949 & IN HOSE XT6; & $\$ 0,24$ & $\$ 0,43$ & 937 & 32.27 \\
\hline 70196446 & HOSE ASSEMBLY, NONMETALLIC;LOW \& MEDIUM & $\$ 0,18$ & $\$ 0,33$ & 360 & 20.00 \\
\hline
\end{tabular}

$\mu \mathrm{L}=$ Average Request During Lead Time

$\mathrm{k}=$ Order Fee

$\sigma \mathrm{L}=$ Lead Time Standard Deviation

$\mathrm{h}=$ Holding Cost

$\mathrm{B}=$ Shortage cost

$\mathrm{SS}=$ Safety Stock

\section{RESEARCH METHOD}

The research stages in this research was adapted from [1517]. The focus of this research is to determine the minimum and maximum stock to reduce inventory costs and increase service level. The first stage in this research is to classify spare parts by using $\mathrm{ABC}$ analysis for heavy equipment. $\mathrm{ABC}$ Analysis follows the 80-20 principle or pareto law, where $80 \%$ of the total value of material inventory is represented by $20 \%$ of inventory material [3]. Second stage is, selecting ten spare parts from ABC analysis for further analysis. The next stage is to classify the spare parts based on ADI - CV analysis. The last stage is calculate and analyses minimum and maximum stock based on EOQ and continuous review

\section{RESULTS AND DISCUSSIONS}

Based on primary data and secondary data, we summaries the stock out in several spare parts on heavy equipment such as Berco CR7609, Berco CR7529, Hose assembly nonmetallic and others in Table 1, the stock out of spare parts on heavy equipment were described. Berco CR7609 \& Berco CR7529 are track links which part of dozer undercarriage. Undercarriage is the part of a moving dozer that is underneath the main body of the Dozer. The undercarriage is one of the most expensive components on the dozers. The undercarriage of a dozer is built on a system of moving components: rollers, idlers, track links and other parts. Hose is one of the spare parts used in heavy equipment that serves to deliver fluids in a flexible form. Hydraulic hoses are used for high pressure fluid power applications on mobile and fixed machinery. Acquiring the proper hydraulic hose for any application is essential to the proper operation and safe use of hydraulics and related equipment. This type is for low and medium hydraulic pressure.

Ordering cost, holding cost and shortage cost were also calculated to be used to determine analysis and control the spare parts inventory such as safety stock and reorder point (ROL) and others. We selected 10 spare parts items to determine minimum and maximum stock. In Table 2 shows the ordering cost, holding cost and shortage cost of spare parts on heavy equipment.

The next stage in data processing is to group inventory data using $\mathrm{ABC}$ inventory classification. the next step is to set the minimum stock level and maximum stock level to get the optimal order quantity. Calculation of order quantities uses EOQ (economical order quantity) and determination of minimum stock levels and maximum stock levels using a continuous review control $(\mathrm{S}, \mathrm{s})$. In Table 3 , the spare parts data can be grouped into classifications A, B and C whereby using the pareto chart data obtained there are 1323 items included in classification A, 2496 items including classification B and 11139 items including classification C. spare part classification based on ADI-CV factors also determined in Table 4.

In analysis stages, firstly we used EOQ methods to analysis 10 spare parts selected in this study. The EOQ method is used to minimize ordering and storage costs under conditions of a constant demand rate. The results of EOQ method is shown in Table 5.

In continuous review control method calculation, one important thing to consider is the safety factor. Safety factor is used to determine the level of company anticipation in the 
The $6^{\text {th }}$ International Seminar on Science and Technology (ISST) 2020

July $25^{\text {th }}$ 2020, Institut Teknologi Sepuluh Nopember, Surabaya, Indonesia

Table 6.

Minimum and maximum stock using continuous review control method

\begin{tabular}{|c|c|c|c|c|c|c|}
\hline $\begin{array}{l}\text { Material } \\
\text { Code }\end{array}$ & Material Description & $\mathrm{K}$ & $\begin{array}{l}\text { Safety } \\
\text { factor } \\
\text { value }\end{array}$ & $\begin{array}{l}\text { Standard } \\
\text { Lead Time }\end{array}$ & $\mathrm{s}$ & $\mathrm{S}$ \\
\hline 70184949 & IN HOSE XT6; & $97 \%$ & 1.87 & 1.50 & 940 & 1877 \\
\hline 70196436 & HOSE ASSEMBLY, NONMETALLIC;LOW \& MEDIUM & $97 \%$ & 1.88 & 1.50 & 984 & 1965 \\
\hline N/A & Berco CR7609 & $95 \%$ & 1.67 & 1.50 & 790 & 1184 \\
\hline N/A & Berco CR7529 & $95 \%$ & 1.66 & 1.50 & 770 & 1154 \\
\hline 70196446 & HOSE ASSEMBLY, NONMETALLIC;LOW \& MEDIUM & $95 \%$ & 1.64 & 1.50 & 362 & 722 \\
\hline N/A & Berco CR3688 & $92 \%$ & 1.38 & 1.50 & 260 & 389 \\
\hline N/A & Berco CR3685A & $91 \%$ & 1.37 & 1.50 & 250 & 374 \\
\hline 70190919 & SEAL; & $86 \%$ & 1.09 & 1.50 & 49 & 96 \\
\hline N/A & P/N:2306315;TRANSMISSION GP;CAT & $70 \%$ & 0.51 & 1.50 & 1.02 & 15.3 \\
\hline 70291201 & LINK;1,2 TON;MP2726009;BERCO & $53 \%$ & 0.06 & 1.50 & 12 & 16 \\
\hline
\end{tabular}

Table 7.

Comparison of inventory cost

\begin{tabular}{|c|c|c|c|c|c|}
\hline $\begin{array}{c}\text { Material } \\
\text { Code }\end{array}$ & Material Description & $\begin{array}{c}\text { Inventory cost } \\
\text { actual }\end{array}$ & $\begin{array}{c}\text { Inventory cost } \\
\text { EOQ }\end{array}$ & Saving & $\begin{array}{c}\% \\
\text { Saving }\end{array}$ \\
\hline 70291201 & LINK;1,2 TON;MP2726009;BERCO & $\$ 11,885.94$ & $\$ 2,029.70$ & $\$ 9,856.24$ & $82.92 \%$ \\
\hline N/A & P/N:2306315;TRANSMISSION GP;CAT & $\$ 236,842.95$ & $\$ 102,503.34$ & $\$ 134,339.61$ & $56.72 \%$ \\
\hline 70190919 & SEAL; & $\$ 816.18$ & $\$ 451.14$ & $\$ 365.04$ & $44.73 \%$ \\
\hline N/A & Berco CR3685A & $\$ 1,623.25$ & $\$ 1,233.84$ & $\$ 389.40$ & $23.99 \%$ \\
\hline N/A & Berco CR3688 & $\$ 6,843.10$ & $\$ 5,249.55$ & $\$ 1,593.56$ & $23.29 \%$ \\
\hline 70196446 & HOSE ASSEMBLY, NONMETALLIC;LOW \& MEDIUM & $\$ 66.55$ & $\$ 59.95$ & $\$ 6.59$ & $9.91 \%$ \\
\hline N/A & Berco CR7529 & $\$ 16,598.69$ & $\$ 15,047.64$ & $\$ 1,551.06$ & $9.34 \%$ \\
\hline N/A & Berco CR7609 & $\$ 16,990.22$ & $\$ 15,438.96$ & $\$ 1,551.26$ & $9.13 \%$ \\
\hline 70184949 & IN HOSE XT6; & $\$ 208.40$ & $\$ 199.91$ & $\$ 8.49$ & $4.07 \%$ \\
\hline 70196436 & HOSE ASSEMBLY, NONMETALLIC;LOW \& MEDIUM & $\$ 327.10$ & $\$ 314.36$ & $\$ 12.74$ & $3.89 \%$ \\
\hline
\end{tabular}

event of a shortage of spare parts. Safety factor calculate as follow in Table 6.

Based on comparison between actual inventory cost calculations with inventory cost calculations using EOQ, the highest saving is found in spare parts LINK; 1.2 TON; MP2726009; BERCO with savings cost of $82.92 \%$ then P / $\mathrm{N}$ : 2306315; TRANSMISSION GP; CAT with saving cost of $56.72 \%$, while the smallest saving is in HOSE XT6 with saving of $4.07 \%$ and HOSE ASSEMBLY, NONMETALLIC; LOW \& MEDIUM with saving cost of $3.89 \%$. The result of comparison can be shown in Table 7 .

\section{CONCLUSION}

The main objectives of this research is to determine minimum (safety stock) and maximum inventory level in order to reduce stock out and overstock of spare part inventory on heavy equipment. Saving costs of spare parts based on comparison between actual inventory costs and inventory costs based on EOQ method such as for $82.92 \%$ saving on material for material Link;1,2 ton; MP2726009; Berco and $56 \% .72 \%$ for $\mathrm{P} / \mathrm{N}: 2306315$; Transmission GP;CAT. Generally, reducing inventory cost could be conducted in case study.

Practical implications for case study are inventory classification data in SAP database has been completed based on results of $\mathrm{ABC}$ classification in this study. Now, the case study was using EOQ and continuous review control to determine minimum and maximum stock for heavy equipment and in future other categories will used EOQ and continuous review. The limitation of this research is exploring the criticality and lead time of spare parts and the period of major maintenance each heavy equipment. Future research can determine minimum and maximum spare parts consider the criticality, lead time, and period of major maintenance.

\section{REFERENCES}

[1] Endrenyi, J., et al. (IEEE/PES Task Force on Impact of Maintenance Strategy on Reliability). (2000). The present status of maintenance strategies and the impact of maintenance on reliability. IEEE Transactions on Power Systems 16(4): 638- 646.

[2] Dekker, R. (1996). Applications of maintenance optimization models: A review and analysis. Reliability Engineering and System Safety 51: 229-240.

[3] M. Rosienkiewicz, et al., "A hybrid spares demand forecasting method dedicated to mining industry," Applied Mathematical Modelling, vol. 49, pp. 87-107, 2017.

[4] B. Ghodrati, et al., "Spare parts estimation and risk assessment conducted at Choghart Iron Ore Mine," Journal of Quality in Maintenance Engineering, 2007.

[5] I. Kurniawan and I. Vanany, "Analisis Risiko Kerusakan Peralatan Dengan Metode Probabilistik FMEA Pada Industri Minyak dan Gas," Surabaya. Tugas Akhir Jurusan Teknik Industri ITS, 2013.

[6] D. Ariyani and I. Vanany, "Risk Assessment dengan Simulasi Monte Carlo dan mitigasinya Pada Industri Compressed Natural Gas," ed: Institut Teknologi Sepuluh Nopember Surabaya, 2013.

[7] A. E. Wulandari and I. Vanany, "Perancangan Dan Pengukuran Sistem Kinerja Lingkungan Untuk Mendukung Proper Pada Industri Gas," BISMA (Bisnis dan Manajemen), vol. 10, pp. 61-72, 2017

[8] Kumar, S. (2004). Spare Part Management - An IT Automation Perspective.

[9] Sim, S.H. \& Endrenyi, J. (1988). Optimal preventive maintenance with repair. IEEE Transactions on Reliability 37(1): 92-96.

[10] Tampubolon, Dr. Manahan P., 2004, Manajemen Operasional (Operation Management), Ghalia Indonesia, Jakarta.

[11] Aini, (2011), Manajemen Persediaan, Edisi 1, Jakarta.

[12] Barry, Render dan Jay Heizer. 2001. Prinsip-prinsip Manajemen Operasi : Operations Management. Jakarta : Salemba Empat.

[13] Dunn S 1998 Maintenance Conf Proc, Queensland, Australia.

[14] Xiao L, Song S, Chen X and Coit D W 2016 Joint optimization of production scheduling and machine group preventive maintenance Reliab. Eng. Syst. Saf. 146 68-78

[15] Kharisma, G., Pengklasifikasian Dan Peramalan Spare Part Di Industri Pupuk (Studi Kasus: PT. Petrokimia Gresik). 2013, Institut Teknologi Sepuluh Nopember. 
IPTEK Journal of Proceedings Series No. (6) (2020), ISSN (2354-6026)

The $6^{\text {th }}$ International Seminar on Science and Technology (ISST) 2020

July $25^{\text {th }} 2020$, Institut Teknologi Sepuluh Nopember, Surabaya, Indonesia

[16] Nugroho, H.W. and I. Vanany. Pengklasifikasian Spare Part dan Model Pemilihan Vendornya pada MeteringStation di PT Chevron Pacific Indonesia. in Prosiding Seminar Nasional Manajemen dan

[17] Farah, Hilma (2019), "Pengendalian Persediaan Spare Part Mesin pada Teknologi. 2013. 